\title{
Grayscale Image
}

National Cancer Institute

\section{Source}

National Cancer Institute. Grayscale Image. NCI Thesaurus. Code C85845.

An image composed of pixels with varying intensities of a single color. 